ISSN: $2455-104 X$

Volume 4,Issue 2 (July-December) 2018,23-26

Received: 23 Oct .2018 ; Accepted: 31 Oct. 2018 ; Published: 13 Nov. 2018 ; Paper ID: IJRLS-1294

\title{
Mobile Technology using in Library services
}

\author{
Vijay Chhaburao Rahane
}

\author{
Asst. Librarian, \\ MET's Institute of Technology- Polytechnic Bhujbal Knowledge City, Adgaon, Nashik-3 \\ E-mail: rahanevijay@gmail.com
}

\begin{abstract}
In the new era digital technological revaluation is the challenge for the Library Information science not only in India but also abroad. The user satisfaction in Library field is very importance and challengeable job today. Librarian must need to show the tendency for various required services to patrons. It's the vision for $21^{\text {st }}$ century Librarianship. The quality of LIS professionals has also improved for output in new dimensions. Increase the usage and access by the Information and Communication Technology (ICT). This paper discusses the Mobile Technology best service in Library.
\end{abstract}

\section{Keywords: Mobile Technology, Network, Mobile Library services}

\section{INTRODUCTION}

Today, in an environment of information and publication explosion it has become practically impossible for any library to remain self reliant. In a situation of growing demand of the readers and depleting level of financial resources, no library is able to obtain all the material on demand. New Technology using in the library services. Mobile computing is transforming how people search, receive and interact within formation on a daily basis. In just a few short years smart phone android mobile ownership has skyrocketed and popular use of e-readers has been steadily on the rise. These advanced mobile tools provide portable, direct access to the world of information, across boundaries of subject, discipline and industry. Libraries are fully engaged in the process of adapting to increased demand for electronic collections and the ongoing acquisition and archiving of born digital content. Supporting mobile access to these resources is the next step, and mobile efforts are under way. These are challenging economic times for libraries to take on new technological initiatives, yet librarians across the country and internationally are seeking creative solutions to providing mobile library services. Link the mobile user to the physical and virtual collections offered by the library - thus enhancing the user's experience and expanding the reach of the library's rich and diverse collections. Technological skill and programming ability are often cited as barriers to implementing mobile technologies.

\section{INTERNET AND MOBILE TECHNOLOGY}

Mobile technology is altering and extending the ways we communicate, conduct business, teach, learn, entertain ourselves, and make consumer decisions. It is bringing the Internet into our daily lives, enabling the retrieval and broadcast of information from anywhere at any time. Through mobile connectivity, information is becoming intertwined with our lives more profoundly than is the case when we sit down at a desktop or even with a laptop computer. Mobile devices today can run increasingly complex software, interact with cloud services, play rich multimedia content, and allow for advanced user interactivity. New hardware and technologies such as Bluetooth, accelerometers, and multi touch screens, as well as text messaging, android phone software applications, mobile websites, global positioning systems (GPS), Wi-Fi, Bluetooth, mobile hotspot, share it, and media creation and capture tools, are all part of the mobile environment.

There are few places where users are truly disconnected from wireless networks. Even air travel the last refuge for non connectedness is beginning to see the use of Wi-Fi in flight. Thus, mobile devices can send and receive information nearly anywhere at any time. One result is a shift in traditional notions of anonymity and privacy. Whereas telephone conversations 
outside the home or office were once held in the relative privacy of a phone booth, the ubiquity of mobile technology has made us generally more comfortable with living at least this portion of our lives in public. Mobile technology is seeing an increasingly wide range of uses in our daily lives. It is increasing access to timely medical information during an emergency; providing immediate information on product reviews and pricing; facilitating the sharing of information in a crisis or natural disaster; and even enabling citizens to report traffic problems, potholes, or downed power lines to community officials in real time. Mobile devices make our lives more convenient by providing access to useful information such as weather forecasts, bus schedules, bank accounts, and grocery lists. They make commutes or other downtime enjoyable by providing on-the-go access to entertainment, such as e-books, e-journals, games, podcasts, and streaming video. They keep us connected with family, friends, and coworkers through e-mail, text messaging, and access to social networking applications. And they expand capabilities for teaching and learning, providing access to rich multimedia resources and student-centered mobile applications.

\section{ENABLING LIBRARIES TO PROVIDE EXPANDED SERVICES TO USERS}

Libraries can better serve their users by embracing the growing capabilities of mobile technology. They can promote and expand their existing services by offering mobile access to their websites and online public access catalogs; by supplying onthe-go mobile reference services; and by providing mobile access to e-books, journals, video, audio books, and multimedia content. Thus audio/video collections no longer are composed only of physical units to borrow, but increasingly are streamed on-demand or downloaded, circulating content in urban, suburban, and rural libraries. Mobile devices and services therefore provide tremendous flexibility for those who wish to take advantage of library services. With a simple $4 \mathrm{G}$ connection, a user lying on a beach can access e-books and multimedia content via his or her local library. If a smart phone can always access a network, content can be continually streamed to the device over the network, providing content on demand and making it unnecessary to maintain a local copy of the material. By going mobile, then, a library takes a giant step toward becoming a round-the-clock service. The mobile environment can also offer new venues for teaching digital literacy skills to youth as well as adults, and aid libraries in their outreach as consumer educators. Through the continued adoption of mobile technology, library services can potentially engage traditionally underserved groups as well. For example, while ethnic minority populations are connected to broadband at home less than are other demographic groups, they carry cell phones at the same rate and access the Internet via mobile devices at higher rates than whites.

\section{LIBRARY AND MOBILE TECHNOLOGY}

Mobile devices create privacy concerns that do not arise in the physical environment of the library because there are limits to the tracking of physical content. In the past, customers had to travel to their local library to access the card catalog, check out books and other materials, ask questions of librarians, and participate in job workshops or library events. Although they had to take the time to get to the library building, they could use the library services with a reasonable amount of anonymity. Libraries have developed strong privacy protections for their users, especially in relation to borrowing records. When users check out physical media such as books, magazines, or multimedia materials, they can be assured that the library will not reveal their circulation records or other personal information without a court warrant. additionally, the nature of the material - the physical book, magazine volume, or DVD_prevents the library or other entities from gleaning much additional information about how the material was being used. Information technology, by contrast, offers the nearly limitless ability to capture granular information on both users and uses of content, with important consequences for freedom of inquiry. While most large data networks are relatively secure, and most libraries take care to secure their Wi-Fi networks, users communicating from outside of the library may be texting, e-mailing, or sending/receiving other information via unsecured networks. Moreover, the pervasive connectivity of many mobile devices makes them capable of collecting and transmitting data on how content is being consumed and by whom.

\section{MOBILE TECHNOLOGY AND LIBRARY SERVICES}

- $\quad$ Following are possible ways to send SMS from libraries, [Kumar \& Chitra, 2008]

- $\quad$ SMS alert services

- Few Library automation software provide option to send SMS alerts for reserved items, due items to users. For example, Libsys 0.7

- $\quad$ Plug-ins integrated with library email system to enable email to SMS messaging.

- Outsourcing the contract to a vendor to send alert services.

SMS alert service 
- $\quad$ Libraries might use SMS services in the following domains (M-Libraries, 2012).

- To send SMS to collect the requested books

- Reminding the user if, book is due in his/her account; informing user about the exact fine.

- Acknowledging the user about renewal of a book.

- OPAC service.

- Users may request the opening and closing hours of the library.

A list of possible mobile service is listed below:

1. Mobile library site

2. Mobile On-line Public Access Catalogue (MOPAC)

3. Circulation services

4. Reference Enquiry services

5. Current Awareness Service and Selective Dissemination of Information Service (CAS \& SDI)

6. E-mail and SMS -Service

7. Distribution of E-Resources through Mobile site

8. Library Maps and floor plans

9. Library News, Events and Blogs

10. Library Hours and library tours

11. Mobile databases

12. Inter library loan service

13. List of new Arrivals

14. Books and Articles search

15. Mobile apps for library

16. Library instructional program through mobile site

17. Photo/Video gallery

18. Subject guide, path-finders etc.

19. Library Surveys

20. Feedback / Comments / Suggestions

\section{CONCLUSION}

Mobile phones are inevitable tools for information communication. Human beings in a society use mobile phone to communicate thoughts, facts, conversations, in general, information. The dissemination of processed information is a common factor in a civilized society. Several organizations such as libraries, documentations centers involved in this process. Libraries especially use several tools and techniques to circulate the information to the user community. At the same time, libraries should be advertised. For this purpose the use of technology is very essential. Mobile technology has become boon to the libraries. A library may reach the remote users effectively by adopting of mobile technology in its services.

\section{REFERENCES}

[1]. Ed Bayley, “An E-Book Buyer's Guide to Privacy,” Electronic Frontier Foundation, December 21, 2009, http://www.eff.org/deeplinks/2009/12/e-book-privacy 
[2]. Galvin, Denis and Sun, Mang (2011). Using Web Services for a Mobile OPAC. Code\{4\}lib Journal, 13, Retrieved from, http://journal.code4lib.org/articles/4810

[3]. Hanson, W. Cody. (2011). Libraries and Mobile Services. American Libraries Magazine, Retrieved from, http://americanlibrariesmagazine.org/columns/dispatches-field/libraries-and-mobile-services

[4]. International Telecommunication Union, "Measuring the Information Society 2010," p. 1,http://www.itu.int/ITUD/ict/publications/idi/2010/Material/MIS_2010_Summary_E.pdf

[5]. John Paczkowski, “OMFG: 4.1 Billion Text Messages Sent Every Day in U.S.” Digital Daily (October 8, 2009), http://digitaldaily.allthingsd.com/20091008/omfg-4-1-billion-text-messages-sent-every-day-in-us

[6]. Kumar, Vimal. \& Chithra, S. (2008). Innovative use of SMS Technology for the excellence in library services of Kerala. In IASLIC 23rd National Seminar On Library Profession in Search of a New Paradigm, Bose Institute, Kolkata, December 10-13,

[7]. M-Libraries. (2012). Retrieved from http://libsuccess.org/index.php?title=M-Libraries

[8]. Shrivastav shail, Use of mobile Technology in Library Information services, American Research Thoughts.vol-1, issue7.pp1532-1538, 2015.

[9]. Timothy Vollmer is a consultant to the American Library Association's (ALA) Office for Information Technology Policy (OITP). This policy brief is the result of a literature review, consultations with selected library and technology policy experts, an exploratory panel session at the 2009 ALA Annual Conference, a presentation at the 2009 Library and Information Technology Association (LITA) National Forum, and iteration among OITP committee members.

[10]. http://www.alatechsource.org/ltr/on-the-move-with-the-mobile-web-libraries-and-mobile-technologies 